\title{
Effect of Physical Training Towards Body Balance in Overweight Condition
}

\author{
Purwo Sri Rejeki ${ }^{*}$, Anita Faradilla Rahim ${ }^{2}$, Rizka Eka Prasetya ${ }^{3}$ \\ ${ }^{1}$ Department of Physiology, Sport Health Science Program, Faculty of Medicine, Universitas Airlangga - Dr. Soetomo \\ General Hospital, Surabaya, Indonesia \\ ${ }^{2}$ Sport Health Science, Faculty of Medicine, Universitas Airlangga - Dr. Soetomo General Hospital, Surabaya, Indonesia \\ ${ }^{3}$ Faculty of Medicine, Universitas Airlangga, Surabaya, Indonesia
}

\author{
A R T I C L E I N F O

\section{Article history:} \\ Received 9 October 2018 \\ Received in revised form 1 \\ November 2018 \\ Accepted 8 November 2018 \\ Available online 30 November \\ 2018 \\ Keywords: \\ Body balance, \\ Overweight, \\ Physical training.

\section{*) Corresponding author:} \\ purwo_faal@yahoo.com
}

\section{Introduction}

As the technology and era change from year to year, morphological and physiological changes occur not only in elderly, but also occur in younger age, around 18-22. ${ }^{1}$ World Health Organization (WHO) reported in 2016, approximately 1,9 billion adults over 18 years old, were categorized overweight with a prevalence of $39 \%$ man and $40 \%$ woman. High prevalence $(62 \%)$ still occurs in the developed countries such as America and Europe, while in Southeast Asia $(14 \%),{ }^{2}$ and Indonesia reached $13,5 \% .^{3}$ An overweight person has morphological changes in the muscle, resulting functional impairment especially in muscle strength and contraction, muscle elasticity and flexibility, also decreased proprioceptive which can lead to reduction in body balance system. ${ }^{4}$

Balance is a body relative ability controlling center of gravity towards base of support. ${ }^{1}$ Balance also can be defined as an ability to maintain both static and dynamic equilibrium on various positions. ${ }^{5}$ Static balance means the ability of the body to maintain position in which center of gravity (COG) is in a stationary state, not moving. ${ }^{6}$ Dinamic balance means the ability to keep body stability when moving or a movement part or whole of the body from one point to another. ${ }^{7}$ In order to improve body balance, physical training is needed, which involves muscle strengtehing, increasing postural stability, also practicing somatosensory system. Physical training that is performed regularly, sistematically and continuously, grouped into a training program can improve physical ability. ${ }^{8}$

\section{Balance and Overweight}

Overweight is an abnormal or excessive accumulation of fat leading to some health problems, caused by energy imbalance where energy input is more than output, ${ }^{2}$ and store it in adipose tissue. ${ }^{9}$ The parameter to determine overweight is anthropometry examination including body weight and height measurement to calculate Body Mass 
Index (BMI). A person can be categorized into overweight if BMI reached 25 until $29,9 \mathrm{~kg} / \mathrm{m}^{2},{ }^{10}$ while according to Asia Pacific Perspective, overweight was those whose BMI was 23 until $24,9 \mathrm{~kg} / \mathrm{m}^{2} .{ }^{11}$

WHO database in 2016 showed more than 1,9 million people aged 18 or over were identified as overweight, and 600 million of them were obese. ${ }^{2}$ An overweight percentage was influenced $70 \%$ by environmental factor and $30 \%$ by genetic factor. ${ }^{12}$ The environmental factors that contribute greatly are low physical activity and unhealthy food consumption. ${ }^{13}$ Some negative effects of overweight are degenerative diseases such as osteoarthritis, vascular disease, diabetes mellitus, cancer, and others. ${ }^{14}$

Body balance development is affected by sensory information system, synergistic sensory muscle response, muscle strength, adaptation system, and joint motion. ${ }^{15}$ An overweight person will experience a decrease in abdominal muscle strength ${ }^{16}$ and shift in COG. ${ }^{17}$ An increase of fat mass in abdominal region contributes to COG displacement into anterior. ${ }^{18}$ This displacement increases the amount of ankle torque needed to maintain body balance in an upright position, in addition, COG displacement also contributes to a body stability by placing gravity lines close to base of support. ${ }^{17}$

The accumulation of adipose tissue and an excessive increase of body mass can decrease muscle mass, resulting muscle response disorder and loss of body stability mechanism. ${ }^{19}$ Overweight person has lower muscle strength level that can decrease the joint motion. This joint motion is an important aspect in balance, especially in back bones and lower extremit. ${ }^{20}$ Proprioceptive is an afferent information produced internally and occurs from peripheral area of the body which contributes to joint postural and stability control. Proprioceptive consists of sense of joint position, kinesthesia, and sense of resistance and strength. ${ }^{21}$ It can be concluded that proprioceptive is the most important part in the maintenance of a balance.

\section{Physical Activity}

Training is a process or a time period needed by the athlete to achieve a high standard performance by exercising repeatedly and systematically while increasing the loads. ${ }^{22}$ Training is divided into two types, that are acute exercise and chronic exercise. Acute exercise is a training performed in a period of time, called exercise, while chronic exercise is a training performed repeatedly in several days or months and it is called a training. ${ }^{23}$ Every physical training will cause responses or reaction from organs towards training dose or training load. Training dose means measurement of training load that is given to the body. Some factors influence training including training intensity, frequency, and duration. ${ }^{24}$

\section{Stretching Exercise and Balance}

Stretching is a common term that is used to show a therapeutic maneuver. This maneuver is intended to prolong shortening of soft tissue structure pathologically or non-pathologically, so that can increase tissue flexibility. Stretching helps the body to maintain and increase the elasticity of muscle, tendon, fascia, ligament and joint motion. ${ }^{25} \mathrm{~A}$ study about the effect of stretching towards body balance in young and old adults showed that stretching can improve balance. Balance improvement occurs through neurophysiology effect of stretching which involves mechanoreceptor stimulation that consists of muscle spindle and Golgi Tendon Organs (GTO) by providing information to Central Nervous System (CNS) through musculotendinous extension and tension. ${ }^{26}$ Muscle spindle is the biggest sensory organ of muscle to accept and transfer the change of muscle extension and length acceleration and has impact on speed and maintaining muscle condition, ${ }^{27}$ while GTO is a sensory organ located close to musculotendinous intersection and extrafusal muscle, has the role to observe every changes in muscle-tendon tension. ${ }^{25}$

While stretching, muscle spindle responds to an increase of muscle tension then transfer the information to $\mathrm{CNS}$, and the impulse turns back to muscle spindle from spinal cord so it creates contraction reflex of the muscle. ${ }^{27}$ On the contrary, GTO will show autogenic inhibition effect, which block the tension of muscletendon unit, especially if there is prolonged stretch strength. That information will send to CNS and cause muscle relaxation reflex. ${ }^{25}$ In summary, muscle spindle and GTO are the dominant proprioceptor information to maintain balance. If stretching performed as part of training, so the proprioceptor receptor in balance control will be stimulated so that somatosensory system can adapt in balance maintaining trough increasing of muscle flexibility and range of motion.

\section{Resistance Exercise and Balance}

Body movement is defined as the result of increased muscle tension as a motoric response. Muscle strength can be described as the muscle ability to hold the load both external and internal loads. Muscle strength of the ankle, knee and hip must be adequate to maintain body balance when external force given. ${ }^{28}$ Resistance exercise is a strengthening exercise which actively performed both static or dynamic by contracting muscle and withstanding the power given manually or mechanically. ${ }^{25}$ Resistance exercise may increase muscle performance through physiological adaptation that involves neurological adaptation and musculoskeletal adaptation. Neurological adaptation is caused by the efficiency of the neuromuscular system towards the increase of motor units. Contraction strength of the muscle can be directly related to the number of muscle fibers involved, the more motor unit can be recruited, the stronger muscle will contract. Moreover, the more muscle fibers which are innervated by motoric nerve, the 
greater muscle power and strength. ${ }^{27} \mathrm{~A}$ continuously resistance exercise causes musculoskeletal adaptation towards increased mass of the hypertrophy muscle as the result of increased myofibrillar volume. Hypertrophy phenomena also affect the increase in the muscle power, strength and endurance so can improve balance system dynamically. ${ }^{25}$

\section{Proprioceptive Training and Balance}

The important part of balance maintenance is proprioceptive, which means the ability to sense joint position or body in movement ${ }^{29}$ which is located around the muscle and joint structure. Proprioceptive function is described in three methods, firstly, the information from proprioceptive helps protect the joint from excessive movement which may be harmful through reflex mechanism, secondly, proprioceptive gives information about joint stability as long as postural in static state, and the third is proprioceptive helps the coordination of movement performance in the right way. ${ }^{30}$ There are various training which can increase body balance by increasing the proprioceptive. One of it is by using balance board. It is a training on the unstable surface, so that it stimulates mechanoreceptor that activates joint sense or joint proprioceptive system which is very influential on intrafusal tissue (myofibril) and extrafusal fiber (Golgi Tendon Organ). This may directly affect the musculoskeletal and neuromuscular system. A study performed by Berbudi for his sedentary college students, found a significant increase of body balance in 4 weeks. ${ }^{31}$

The principle in this exercise is to improve the function of the body balance controller, namely the sensory information system, central processing, and effector to be able to adapt to environmental changes. During exercise, the intrafusal and extrafusal fibers are received to enrich sensory input that will be sent and processed in the brain so it can determine how much muscle contraction is given. ${ }^{32}$ Some responses are sent back to the extrafusal and activate the golgi tendon and improve the coordination of the intrafusal and extrafusal fibers with the afferent nerve in the muscle spindle, hence producing a good proprioceptive.

\section{Conclusion}

Performing physical training that includes stretching and resistance exercise can improve body balance in an overweight person. A good proprioceptive is needed to maintain body balance, and it can be made through a training using balance board.

\section{Conflict of Interest}

The author stated there is no conflict of interest.

\section{References}

1. Yuliana S, Adiatmika I, Muhammad I, Dhofirul F and Ikrom A. Pelatihan Kombinasi Core Stability Exercise dan Ankle Strategy Exercise Tidak Lebih Meningkatkan
Keseimbangan Statis pada Mahasiswa S1 Fisioterapi STIKES 'Aisyiyah Yogyakarta. Sport And Fitness Journal. 2014; $2: 63-73$.

2. WHO. Fact Sheets: Obesity and Overweight. World Health Organization, 2018.

3. Dasar RK. Jakarta: Badan Penelitian dan Pengembangan Kesehatan, Departemen Kesehatan, Republik Indonesia, 2013.

4. Suadnyana I, Nurmawan S and Muliarta IM. Core Stability Exercise Meningkatkan Keseimbangan Dinamis Lanjut Usia di Banjar Bebengan, Desa Tangeb, Kecamatan Mengwi, Kabupaten Badung. Denpasar: Universitas Udayana, 2014.

5. Delitto A. The Link Between Balance Confidence and Falling. Physical Therapy Research That Benefits You: (2003).

6. Abrahamova D and Hlavacka F. Age-Related Changes of Human Balance During Quite Stance. Physiological Research Institute of Physiology. 2008; 57.

7. Miller CA. Nursing For Wellness In Older Adult : Theory and Practice, Forth Edition. Philadelphia: Lippincott Williams \& Wilkins, 2006.

8. Astrand P, Rodahl K, Dahl H and Stromme S. Textbook of Work Physiology: Physiological Bases of Exercise. New York: Mc Graw-Hill Book, 2003.

9. Sherwood and Lauralee. Human Physiology: From Cells to Systems, Ninth Edition. Canada: Cengage Learning., 2016.

10. WHO. Body Mass Index - BMI. Copenhagen: WHO Regional Office for Europe, 2018.

11. WHO. International Association for the Study of Obesity and the International Obesity Task Force. The Asia-Pacific Perspective : Redefining Obesity and Its Treatment. Western Pacific Region. Crows Nest, NSW, Australia: Health Communications Australia, 2000.

12. Soegih R and Wiramihardja K. Obesitas Permasalahan dan Terapi Praktis. Jakarta: Sagung Seto, 2009.

13. Guyton A and Hall J. Buku Ajar Fisiologi Kedokteran: Edisi 12. Indonesia: Elsevier, 2014.

14. Khomsan A. Pangan dan Gizi untuk Kesehatan. Jakarta: PT Raja Grafindo Persada, 2004.

15. Suhartono. Pengaruh Kelelahan Otot Anggota Gerak Bawah terhadap Keseimbangan pada Subyek Sehat 2005.

16. Karunia S, Wibawa A and Adiputra L. Hubungan Indeks Massa Tubuh (IMT) dengan Keseimbangan Statis pada Mahasiswa Fakultas Kedokteran Universitas Udayana. . Majalah Fisioterapi Indonesia 2015; 2.

17. Corbeil P, Simoneau M, Rancourt D, Tremblay A and Teasdale N. Increased Risk for Falling Associated with Obesity : Mathematical Modeling Of Postural Control. IEEE T Neuron System Rehabilitation 2011; 9: 126-36.

18. Berrigan F, Simoneau M, Tremblay A, Hue O and Teasdale $\mathrm{N}$. Influence of Obesiity on Accurate and Rapid Arm Movement Perfomed from A Standing Posture. International Journal Obesity. 2006; 30: 1750-7.

19. Greve J, Alonso A, Bordini A and Camanho G. Correlation Between Body Mass Index and Postural Balance. Clinics. 2008; 62: 717-20.

20. Wojcik L, Thelen D, Schultz A, J AM and Alexander N. Age and Gender Differences in Peak Lower Extermity Joint Torques and Ranges of Motion Used During Single-Step Balance Recovery from Forward Fall. Journal Biomechanic 2001; 34: 67-73.

21. Riemann B and Lephart S. The Sensorymotor System Part I : The Physiologic Basis of Functional Joint Stability. Journal Athletic Training. 2002; 37: 71-9. 
22. Harsono. Manusia dan Latihan. Bandung: ITB, 1996.

23. Mc. Ardle W, Kach F and Kach V. Exercise Physiology: Energy, Nutrition and Human Performance. Philadelphia: Lea \& Febiger, 2010.

24. Fox E, Bower $\mathrm{R}$ and Foss $\mathrm{M}$. The Physiological for Exercise And Sport. . Lowa: WBC Brown And Benchmark, 1993.

25. Kisner C and Allen L. Therapeutic Exercise. Philadhelpia: Davis Company, 2007.

26. Wallmann HW, Kirk RP and Matthew B. Acute Effect of Static Stretching on Balance in Young Versus Eldery Adults. Physical and Therapy Occupational In Geriatrics. 2012; 30: 301-5.

27. Higgins M. Therapeutic Exercise : From Theory to Practice. Philadephia: F.A Davis Company., 2011.

28. Nugroho S. Materi Kinesiologi. Yogyakarta: Universitas Negeri Yogyakarta, 2011.

29. Brown S, Miller W and Eason J. Neuroanatomy And Neuromuscular Control of Movement. Exercise Physiology: Basis Of Human Movement In Health And Disease Philadephia: Lippincott Williams \& Wilkins, 2006.

30. Jha P, Irshad A, Sonal K, Kamran A, Shalini V and Taru K. Proprioception : An Evidence Based Narrative Review. Research \& Investigations In Sport Medicine. 2017.

31. Berbudi A. Pelatihan Core Stability dan Balance Board Exercise Lebih Baik dalam Meningkatkan Keseimbangan Dibandingkan dengan Balance Board Exercise pada Mahasiswa Usia 18-24 Tahun dengan Kurang Aktivitas Fisik. Journal Fisioterapi. 2015; 15.

32. Brown L. Strength Training. United States Of America: Human Kinetics, 2007. 